\title{
Analysis of Expert Assessments of Opportunities and Threats To Innovative Development of Regional Economies
}

\author{
Risin I.E.* \\ Voronezh State University \\ Voronezh, Russia \\ E-mail: risin@mail.ru \\ Sysoyeva E.F. \\ Voronezh State University \\ Voronezh, Russia \\ E-mail: selfin@mail.ru
}

\author{
Treshchevsky Yu.I. \\ Voronezh State University \\ Voronezh, Russia \\ E-mail: utreshevski@yandex.ru \\ Nikitina L.M. \\ Voronezh State University \\ Voronezh, Russia \\ E-mail: lanikitina@yandex.ru
}

\author{
Kosobutskaya A.Yu. \\ Voronezh State University \\ Voronezh, Russia \\ E-mail: anna.rodnina@mail.ru
}

\begin{abstract}
Focusing the resources and actions of public authorities on the achievement of strategic goals of regional economy development is associated with the formation of substantiated ideas about opportunities and threats of its innovative renewal, predicted in the internal and external environment. Identification of the mentioned opportunities and threats, assessment of their power and probability are among the weakly structured problems. These problems are mainly expressed in qualitative features and are difficult to describe quantitatively. Their decision demands expert assessments. The article contains the analysis of the results of the expert group survey ( 32 respondents). The experts have assessed opportunities and threats to innovative development of the economy that are predicted in the external and internal environment of Russian regions. The list of opportunities and threats that are the most significant in terms of impact, probability of occurrence, and the consequences of such threats were determined. The levels of their formation and the parties influencing their implementation were identified. The obtained assessments allow increasing the validity of public authorities' decisions and actions designed to provide the achievement of regional development strategic goals.
\end{abstract}

Keywords - regions, innovative development of economy, opportunities, threats, expert estimations.

\section{INTRODUCTION}

The strategic development of Russian regions at present is largely focused on the development and implementation of digital technologies in the context of general innovative development. N.A. Serebryakova, Y.A. Salikov, O.Y. Kolomytseva et al. [1]; E. Sibirskaya, O. Stroeva, I. Lyapina et al. [2]; T.I. Ovchinnikova, I.N. Bulgakova, S.V. Sviridova et al. [3, 4]; V.N. Parahina, O.A. Boris, T.L. Bezrukova, I.I. Shanin [5]; V.A. Arsenyeva, S.A. Litvinova, V.N. Parakhina, Z.N. Kozenko, M.Y. Denisov [6]; N.A. Kulagina, O.V. Mikheenko, D.G. Rodionov et al. [7] pay attention to the problem.
Yu.V. Vertakova, O.N. Grechenyuk, A.V. Grechenyuk [8] rightfully argues that innovation should be disseminated both in the technical and technological sphere and in other subsystems of socio-economic systems.

The telecommunications segment of the economy, according to A. Polyanin, T. Golovina, I. Avdeeva et al. [9]; V. Plotnikov, E. Leontyev et al. [10], is one of the most significant in modern Russian conditions.

Focusing of public authorities' resources and actions on achievement of strategic goals of regional economy development is connected with formation of reasonable opinions about opportunities and threats of its innovative renewal, predicted in internal and external environment.

The identification of the above mentioned opportunities and threats, assessment of their influence and feasibility relate to weakly structured problems, which are mainly presented in qualitative terms and can hardly be described quantitatively. Solution of the problem requires use of expert assessment.

\section{ARTICULATION OF ISSUE}

A survey of 32 doctors of economic sciences and professors was conducted to obtain and analyze expert assessments. Surveyed work fruitfully in the problematic field of regional economics and represent leading universities of a number of Russian regions: Financial University under the Government of the Russian Federation, Russian Presidential Academy of National Economy and Public Administration (Voronezh branch), Voronezh State University, Voronezh State Technical flagship University, Voronezh State Academy of Engineering Technologies, Orel State University, and South-West State University (Kursk). 


\section{METHOD OF RESEARCH}

The scientific literature recommends various methods of research on innovation processes in socio-economic systems. A number of these methods has been widely discussed in the work of such researchers as Y. Vertakova, O. Grechenyuk, S. Emelianov, A. Grechenyuk [11]; A.V. Kostikova, P.V. Tereliansky, A.V. Shuvaev, V.N. Parakhina, P.N. Timoshenko [12]; N.A. Kulagina, F.Yu. Lozbinev, V.V. Kobischanov, N.N. Ivkina [13]; Yu.I. Treshchevsky, I.E. Risin, L.S. Korobeinikova, V.V. Gavrilov et al. [14].

D.A. Endovitsky, M.B. Tabachnikova, Yu.I. Treshchevsky [15] make good use of expert estimations to assess the status and development prospects of regional subsystems. The questionnaire we developed for obtaining expert assessments contained an open list of opportunities and threats to the innovative development of regional economies. The experts were asked to evaluate (rank) the power and probability of using the opportunities, consequences and probability of realization of threats to the innovative economy development.
If an expert considered the power of an opportunity and the consequences of threat realization to be the most significant, the grade "5" was given, if significant - "4", if minor - "3", if insignificant - "2". If an expert considered the probability of using the opportunity and threat implementation to be very high, the grade "5" was given, if high - "4", average - "3", low - "2". The expert if considered it necessary could add to the list of opportunities and threats and assess them.

\section{DISCUSSION OF RESULTS}

The experts did not complete the list of proposed to assess the opportunities and threats to the innovative development of the regional economy.

Average values of expert assessments for the whole list of possibilities are presented in Tables 1 and 2 .

TABLE I. ASSESSMENT OF THE POWER OF OPPORTUNITIES

\begin{tabular}{|c|c|c|}
\hline \multirow[b]{2}{*}{ Opportunities for innovation economy development } & \multicolumn{2}{|c|}{$\begin{array}{c}\begin{array}{c}\text { Opportunity power } \\
\text { rank }\end{array} \\
\end{array}$} \\
\hline & $\begin{array}{l}\text { Averag } \\
e\end{array}$ & $\begin{array}{c}\text { Coefficient } \\
\text { of } \\
\text { Variation } \\
(\%)\end{array}$ \\
\hline $\begin{array}{l}\text { 1. Development and implementation of federal state programs ensuring innovative development of } \\
\text { economy }\end{array}$ & 4.6 & 11.2 \\
\hline $\begin{array}{l}\text { 2. Development and implementation of regional state programs ensuring innovative development of } \\
\text { economy }\end{array}$ & 4.2 & 21.8 \\
\hline 3. Expanding regional participation in the implementation of the National Technology Initiative & 4.4 & 16.3 \\
\hline $\begin{array}{l}\text { 4. Implementation of PPP projects with participation of higher education institutions and research } \\
\text { institutes }\end{array}$ & 3.8 & 17.6 \\
\hline $\begin{array}{l}\text { 5. Development of innovation infrastructure (engineering centers, technology transfer centers, core facilities } \\
\text { center, technological parks) }\end{array}$ & 4.6 & 11.6 \\
\hline 6. Venture capital inflow & 4.0 & 21.6 \\
\hline 7. Establishment of the intellectual property market & 3.7 & 23.6 \\
\hline $\begin{array}{l}\text { 8. Expansion of training and retraining of specialists possessing competences adequate to the } \\
\text { requirements of innovative economy }\end{array}$ & 4.0 & 17.7 \\
\hline $\begin{array}{l}\text { 9. State support of talented scientists and specialists in scientific, scientific and technological and } \\
\text { innovation activities }\end{array}$ & 4.2 & 19.7 \\
\hline 10. Creation and development of innovation clusters & 3.9 & 23.9 \\
\hline $\begin{array}{l}\text { 11. Opening and development of technology parks with an acceleration program and resource sharing } \\
\text { processing centers }\end{array}$ & 3.8 & 22.1 \\
\hline 12. State support for small innovative enterprises & 4.3 & 16.3 \\
\hline $\begin{array}{l}\text { 13. Creation of scientific and educational centers on the basis of integration of universities and scientific } \\
\text { organizations and their cooperation with organizations of real economy }\end{array}$ & 4.1 & 14.6 \\
\hline 14. Formation of inter-university research centers for the creation and commercialization of innovations & 3.7 & 19.3 \\
\hline $\begin{array}{l}\text { 15. Formation of cooperation with foreign companies on implementation of technological and product } \\
\text { innovations, integration of regional producers into international value chains }\end{array}$ & 4.3 & 11.5 \\
\hline $\begin{array}{l}\text { 16. Creating an environment for on-line communications between innovation developers, business and } \\
\text { government authorities }\end{array}$ & 4.1 & 19.0 \\
\hline $\begin{array}{l}\text { 17. Implementation of information policy aimed at raising the prestige of innovation and scientific } \\
\text { activities, promotion of innovation culture through mass media and the Internet }\end{array}$ & 4.1 & 21.6 \\
\hline 18. Key rate cut by the Central Bank & 3.7 & 27.3 \\
\hline
\end{tabular}




\section{TABLE II. ASSESSMENT OF OPPORTUNITY PROBABILITY}

\begin{tabular}{|c|c|c|}
\hline \multirow[b]{2}{*}{ Opportunities for innovation economy development } & \multicolumn{2}{|c|}{$\begin{array}{c}\text { Opportunity } \\
\text { probability rank }\end{array}$} \\
\hline & Average & $\begin{array}{l}\text { Coefficient } \\
\text { of Variation } \\
(\%)\end{array}$ \\
\hline $\begin{array}{l}\text { 1. Development and implementation of federal state programs ensuring innovative development of } \\
\text { economy }\end{array}$ & 4.2 & 15.1 \\
\hline $\begin{array}{l}\text { 2. Development and implementation of regional state programs ensuring innovative development of } \\
\text { economy }\end{array}$ & 3.7 & 33.4 \\
\hline 3. Expanding regional participation in the implementation of the National Technology Initiative & 3.7 & 23.6 \\
\hline $\begin{array}{l}\text { 4. Implementation of PPP projects with participation of higher education institutions and research } \\
\text { institutes }\end{array}$ & 2.9 & 20.8 \\
\hline $\begin{array}{l}\text { 5. Development of innovation infrastructure (engineering centers, technology transfer centers, core facilities } \\
\text { center, technological parks) }\end{array}$ & 3.6 & 20.5 \\
\hline 6. Venture capital inflow & 3.0 & 16.7 \\
\hline 7. Establishment of the intellectual property market & 3.3 & 21.2 \\
\hline $\begin{array}{l}\text { 8. Expansion of training and retraining of specialists possessing competences adequate to the } \\
\text { requirements of innovative economy }\end{array}$ & 3.8 & 17.6 \\
\hline $\begin{array}{l}\text { 9. State support of talented scientists and specialists in scientific, scientific and technological and } \\
\text { innovation activities }\end{array}$ & 3.4 & 29.4 \\
\hline 10. Creation and development of innovation clusters & 3.6 & 20.4 \\
\hline $\begin{array}{l}\text { 11. Opening and development of technology parks with an acceleration program and resource sharing } \\
\text { processing centers }\end{array}$ & 3.3 & 21.2 \\
\hline 12. State support for small innovative enterprises & 3.8 & 17.6 \\
\hline $\begin{array}{l}\text { 13. Creation of scientific and educational centers on the basis of integration of universities and scientific } \\
\text { organizations and their cooperation with organizations of real economy }\end{array}$ & 3.3 & 15.0 \\
\hline 14. Formation of inter-university research centers for the creation and commercialization of innovations & 3.0 & 23.6 \\
\hline $\begin{array}{l}\text { 15. Formation of cooperation with foreign companies on implementation of technological and product } \\
\text { innovations, integration of regional producers into international value chains }\end{array}$ & 3.1 & 33.9 \\
\hline $\begin{array}{l}\text { 16. Creating an environment for on-line communications between innovation developers, business and } \\
\text { government authorities }\end{array}$ & 3.7 & 19.3 \\
\hline $\begin{array}{l}\text { 17. Implementation of information policy aimed at raising the prestige of innovation and scientific } \\
\text { activities, promotion of innovation culture through mass media and the Internet }\end{array}$ & 3.3 & 30.0 \\
\hline 18. Key rate cut by the Central Bank & 3.3 & 21.2 \\
\hline
\end{tabular}

The analysis of expert assessments presented in Tables 1 and 2 allows drawing a number of conclusions.

1. The aggregate of the obtained ranks can be defined as homogeneous: the values of the coefficient of variation in the first table in most cases do not exceed $20 \%$, in the second table - a situation is the same, except for two positions $(2,15)$.

2. The experts' assessments have a rather limited set of possibilities, the impact of which on innovation development can be significant. These include the development and implementation of federal state programs (4.6), the expansion of regional participation in the National Technology Initiative (4.4) and the development of innovation infrastructure (4.6).

Note the consistency of the obtained ranks (the values of variation coefficients are 11.2, 16.3, and 11.6, respectively). While the first opportunity depends to a crucial extent on financial and organizational actions of the Federal Centre, the second and the third opportunities depend, first of all, on initiative and closely interconnected actions of organizations implementing the creative potential, economic entities of the real economy, and public authorities of the region.

It is important to note another thing - experts estimate the probability of realization of the above-mentioned opportunities above average as 4.2,3.7, and 3.6, respectively.

3. The experts gave low ranks to such opportunities as implementation of PPP projects with participation of universities and research institutes (3.8), formation of intellectual property market (3.7), formation of interuniversity research centers (3.7). We believe that the low probability of their implementation, noted by experts $(2.9,3.3$, 3.0 , respectively), has also played a significant role in such a result.

Let us move on to experts' assessments of threats to the innovative development of the regional economies. Their average values for the whole list of threats are presented in Tables 3 and 4. 


\begin{tabular}{|c|c|c|}
\hline \multirow[b]{2}{*}{ Threats to the innovation economy } & \multicolumn{2}{|c|}{$\begin{array}{l}\text { Rank of the threat } \\
\text { impact }\end{array}$} \\
\hline & Average & $\begin{array}{c}\text { Coefficient } \\
\text { of } \\
\text { variation } \\
(\%)\end{array}$ \\
\hline 1. Low budget funding for academic science and higher education & 4.8 & 9.2 \\
\hline $\begin{array}{l}\text { 2. Lack of the wherewithal for financing projects of development and implementation of technological } \\
\text { and product innovations in the real economy }\end{array}$ & 4.7 & 10.7 \\
\hline $\begin{array}{l}\text { 3. Lack of sufficient incentives for banks to provide long-term loans to innovation activities of organizations } \\
\text { in the real sector of economy }\end{array}$ & 4.4 & 11.9 \\
\hline $\begin{array}{l}\text { 4. Reducing incentives for the creation and implementation of innovations due to monopolization and } \\
\text { state control of the economy }\end{array}$ & 3.6 & 20.4 \\
\hline 5. Worsening of the general institutional environment in Russia & 4.2 & 15.8 \\
\hline 6. Barriers to the inclusion of Russian innovation companies in international production cooperation & 4.3 & 20.0 \\
\hline $\begin{array}{l}\text { 7. Lack of tax exemptions and other preferences for clusters and techno-parks engaged in innovation } \\
\text { activities }\end{array}$ & 3.7 & 19.3 \\
\hline 8. Lack of tax exemptions and other preferences for technological entrepreneurship & 3.8 & 22.1 \\
\hline $\begin{array}{l}\text { 9. Lack of state support for joint projects of higher education institutions and industrial partners to } \\
\text { create high-tech industries }\end{array}$ & 3.7 & 19.3 \\
\hline 10. Lack of venture capital market & 3.8 & 22.1 \\
\hline 11. Lack of the necessary legal framework protecting the owners of the results of intellectual activity & 4.0 & 17.7 \\
\hline $\begin{array}{l}\text { 12. Separation of higher education personnel with competences adequate to the requirements of an } \\
\text { innovation economy }\end{array}$ & 3.7 & 30.5 \\
\hline $\begin{array}{l}\text { 13. External sanctions blocking transfer of new technologies developed in foreign countries to Russian } \\
\text { companies }\end{array}$ & 4.0 & 12.5 \\
\hline 14. "Brain drain" of current and potential developers of technological and product innovations & 4.3 & 16.3 \\
\hline 15. Low level of people' innovation culture & 3.7 & 19.3 \\
\hline 16. Low level of business receptivity to innovation & 3.7 & 23.6 \\
\hline $\begin{array}{l}\text { 17. Lack of necessary interconnection of subsystems and individual elements within the regional } \\
\text { innovation system }\end{array}$ & 3.8 & 17.6 \\
\hline 18. High inflation rate & 3.7 & 19.3 \\
\hline $\begin{array}{l}\text { 19. Foreign exchange market volatility and, as a consequence, higher prices for imported equipment and } \\
\text { components }\end{array}$ & 3.9 & 20.1 \\
\hline
\end{tabular}

The analysis of expert assessments presented in Tables 3 and 4 allows drawing a number of conclusions.

1. The aggregate of the obtained ranks can be defined as homogeneous: the values of the coefficient of variation in the overwhelming majority of positions in both tables do not exceed $20 \%$.

2. The experts' assessments contain a rather representative list of threats, the impact of which is high. These include low budget funding of academic science and higher education (4.8), lack of the wherewithal for financing projects of development and implementation of technological and product innovations in the real economy (4.7), lack of sufficient incentives for banks to provide long-term loans to innovation activities of organizations of the real sector of the economy (4.4), barriers to the inclusion of Russian innovation companies in international production cooperation (4.3), "brain drain" of existing and potential developers of technological and product innovations (4.3), worsening of the general institutional environment in Russia (4.2), lack of the necessary legal framework protecting the owners of the results of intellectual activity (4.0), external sanctions blocking transfer of new technologies developed in foreign countries to Russian companies (4.0). 


\begin{tabular}{|l|c|c|}
\hline \multicolumn{1}{|c|}{ Threats to the innovation economy } & $\begin{array}{c}\text { Rank of threat } \\
\text { probability }\end{array}$ \\
\cline { 2 - 3 } & $\begin{array}{c}\text { Coefficient } \\
\text { of } \\
\text { variation } \\
\text { (\%) }\end{array}$ \\
\hline 1. Low budget funding for academic science and higher education & 4.3 & 11.5 \\
\hline $\begin{array}{l}\text { 2. Lack of the wherewithal for financing projects of development and implementation of technological } \\
\text { and product innovations in the real economy }\end{array}$ & 4.3 & 11.5 \\
\hline $\begin{array}{l}\text { 3. Lack of sufficient incentives for banks to provide long-term loans to innovation activities of } \\
\text { organizations in the real sector of economy }\end{array}$ & 4.4 & 11.9 \\
\hline $\begin{array}{l}\text { 4. Reducing incentives for the creation and implementation of innovations due to monopolization and } \\
\text { state control of the economy }\end{array}$ & 3.4 & 15.3 \\
\hline 5. Worsening of the general institutional environment in Russia & 3.3 & 21.2 \\
\hline 6. Barriers to the inclusion of Russian innovation companies in international production cooperation & 4.3 & 16.3 \\
\hline $\begin{array}{l}\text { 7. Lack of tax exemptions and other preferences for clusters and techno-parks engaged in innovation } \\
\text { activities }\end{array}$ & 3.7 & 19.3 \\
\hline 8. Lack of tax exemptions and other preferences for technological entrepreneurship & 3.9 & 20.1 \\
\hline $\begin{array}{l}\text { 9. Lack of state support for joint projects of higher education institutions and industrial partners to } \\
\text { create high-tech industries }\end{array}$ & 3.8 & 17.6 \\
\hline 10. Lack of venture capital market & 3.9 & 15.5 \\
\hline 11. Lack of the necessary legal framework protecting the owners of the results of intellectual activity & 3.6 & 20.4 \\
\hline $\begin{array}{l}\text { 12. Separation of higher education personnel with competences adequate to the requirements of an } \\
\text { innovation economy }\end{array}$ & 3.8 & 22.1 \\
\hline $\begin{array}{l}\text { 13. External sanctions blocking transfer of new technologies developed in foreign countries to Russian } \\
\text { companies }\end{array}$ & 4.1 & 14.6 \\
\hline 14. "Brain drain" of current and potential developers of technological and product innovations & 4.2 & 15.8 \\
\hline 15. Low level of people' innovation culture & 3.6 & 20.4 \\
\hline 16. Low level of business receptivity to innovation & 3.8 & 17.6 \\
\hline $\begin{array}{l}\text { 17. Lack of necessary interconnection of subsystems and individual elements within the regional } \\
\text { innovation system }\end{array}$ & 3.6 & 20.4 \\
\hline 18. High inflation rate & 3.6 & 14.8 \\
\hline $\begin{array}{l}\text { 19. Foreign exchange market volatility and, as a consequence, higher prices for imported equipment } \\
\text { and components }\end{array}$ & 3.9 & 15.5 \\
\hline
\end{tabular}

We would like to draw attention to the high degree of consistency in the ranks of the financial strength of innovative development presented in the first three positions: 9.2, 10.7, and 11.9 , respectively.

Another aspect of the threats analysis is the level at which they are formed and implemented. In this regard, it should be noted that out of the eight threats identified above, three are global. The sole responsibility of the Federal Centre for the presence and reproduction of the threat exists only on one position (low budget funding for academic science and higher education). In other cases, such responsibility has two parties the Federal Centre and the regional public authorities.

It is important to note another point - experts on most of the above-mentioned threats (six positions out of eight) assess their probability as high.

\section{CONCLUSION}

The analysis of the obtained expert assessments allows drawing a number of general conclusions.

1. The substantially narrowed range of opportunities for innovative development of the sub-sovereign entities' economies presented in the assessments, to a certain extent, reflects real economic and managerial practices. The practice is distinguished by the lack of notable public-private partnership projects implemented in the spheres of science and higher education, underdeveloped processes of cooperation between universities in practice-oriented scientific activities, the lack of efficient infiltration of higher education institutions into the internal environment of clusters, industrial and technological parks. The sustainable preservation of such practice generates pessimism of evaluations associated with a reduced probability of using the opportunities of its qualitative renewal.

2 . The wide range of threats to the innovative development of the sub-sovereign entities' economies, as presented in the 
assessments, largely reflects the presence of many 'pain points' inherent in the innovative sphere of the regions. This sphere is notable for its isolation and weak interrelation of its main subsystems (production of innovations, implementation of innovations, resource supply). The prominent role of global threats is determined not only by geopolitical factors, but also by aggravation of competition on global markets of goods and services, key participants of which are not interested in expansion of Russian producers.

3. The achievement of notable progress in the innovative development of the sub-sovereign entities' economies is associated with the systemic actions of public authorities at various levels. These actions cover institutional, economic and social environments and implement effective approaches capable of providing necessary and sufficient incentives to economic agents to use creative and financial resources at their disposal in the innovation sphere. An important condition for changes is the adaptive use of foreign experience in the commercialization of scientific research results, the protection of intellectual property rights and the "filling" of forms of spatial localization of business with innovative content.

\section{References}

[1] N.A. Serebryakova, Y.A. Salikov, O.Y. Kolomytseva, T.A. Pakhomova, N.V. Grishchenko, "Actual issues of planning of well-balanced development of innovative \& investment activities", Asian Soc. Sci., vol. 11 , no. 20, pp. 193-205, 2015

[2] N. Serebryakova, E. Sibirskaya, O. Stroeva, I. Lyapina, "The contents and structure of innovative activity in the Russian economy", Asian Soc. Sci., vol. 10, no. 23, pp. 51-59, 2014.

[3] E. Sibirskaya, O. Stroeva, N. Serebryakova, E. Petruchina, "The need of the uniform information platform "Innovations of Russia" formation", Asian Soc. Sci., vol. 10, no. 23, pp. 78-84, 2014

[4] N.A. Serebryakova, T.I. Ovchinnikova, I.N. Bulgakova, S.V. Sviridova, T.O. Tolstykh, "Innovational methods of development of intellectual labour for economy's security", Europ. Res. Studies J., vol. 20, no. 3B, pp. 556-569, 2017.

[5] V.N. Parahina, O.A. Boris, T.L. Bezrukova, I.I. Shanin, "State support for creation and development of socially-oriented innovative enterprises", Asian Soc. Sci., vol. 10, no. 23, pp. 215-222, 2014.
[6] V.A. Arsenyeva, S.A. Litvinova, V.N. Parakhina, Z.N. Kozenko, M.Y. Denisov, "Innovational development for transitional economy Russia case study", Contemporary Econ., vol. 10, no. 4, pp. 373-380, 2016.

[7] N.A. Kulagina, O.V. Mikheenko, D.G. Rodionov, "Technologies for the development of methods for evaluating an innovative system", Int. J. of Recent Technol. and Engineer., vol. 8, no. 3, pp. 5083-5091, 2019.

[8] Yu.V. Vertakova, O.N. Grechenyuk, A.V. Grechenyuk, "Nontechnological innovations and their impact on the socio-economic development of Russia", no. 2-5, pp. 479-486, 2016 [SGEM International Multidisciplinary Scientific Conf. on Social sciences and Arts]

[9] A. Polyanin, T. Golovina, I. Avdeeva, I. Dokukina, Y. Vertakova, "Digital strategy of telecommunications development: concept and implementation phases", Vision 2020: Sustainable Economic development, Innovation Management, and Global Growth, pp. 1792-1803, 2017 [30th Int. Business Information Management Association Conference, IBIMA, 2017].

[10] V. Plotnikov, Y. Vertakova, E. Leontyev, "Evaluation of the effectiveness of the telecommunication company's cluster management," Economic Computation and Economic Cybernetics Studies and Research. 2016. vol. 10, no. 23, pp. 109-110.

[11] Y. Vertakova, O. Grechenyuk, S. Emelianov, A. Grechenyuk, "Analysis and forecasting of the innovative development of regions and its influence on public economic policy", Education Excellence and Innovation Management through Vision 2020: From Regional Development Sustainability to Global Economic Growth, pp. 1783-1795, 2017 [the 29th International Business Information Management Association Conf., 2017].

[12] A.V. Kostikova, P.V. Tereliansky, A.V. Shuvaev, V.N. Parakhina, P.N. Timoshenko, "Expert fuzzy modeling of dynamic properties of complex systems", ARPN J. of Engineer. and Appl. Sci., vol. 11, no. 17 pp. 10601-10608, 2016

[13] N.A. Kulagina, F.Yu. Lozbinev, V.V. Kobischanov, N.N. Ivkina, "Regional features of functioning of the geoinformation analytical system of innovative potential", J. of Phys.: Conf. Ser., vol. 803, no. 1 , p. $012084,2017$.

[14] Yu.I. Treshchevsky, I.E. Risin, L.S. Korobeinikova, V.V. Gavrilov, "Management of changes of socio-economic systems: economic analysis of the state and consequences of the systemic feature", Studies in Syst. Decision and Control, vol. 135, pp. 21-30, 2018.

[15] D.A. Endovitsky, M.B. Tabachnikova, Yu.I. Treshchevsky, "Analysis of the economic optimism of the institutional groups and socio-economic systems", J. of Advan. Res. in Law and Econ., vol. 8, no. 6, pp. 1745-1752, 2017. 